\title{
PENYULUHAN PENGARUH NEGATIF NARKOBA BAGI MASYARAKAT DI DESA BATTAL KECAMATAN PANJI KABUPATEN SITUBONDO
}

\section{EDUCATION OF THE NEGATIVE EFFECT OF DRUGS FOR THE COMMUNITY IN BATTAL VILLAGE, PANJI DISTRICT SITUBONDO DISTRICT}

\author{
Irma Noervadila $^{1)}$, Yesi Puspitasari ${ }^{2}$, Siti Seituni $^{3)}$ \\ ${ }^{1,2,3}$ STKIP PGRI Situbondo \\ Email: noervadilairma@gmail.com
}

\begin{abstract}
Abstrak: Narkoba adalah barang yang sangat berbahaya dan bisa merusak susunan syaraf yang bisa merubah sebuah kepribadian seseorang menjadi semakin buruk, selain itu narkoba adalah sumber dari tindakan kriminalitas yang bisa merusak norma dan ketentraman umum. Penyalah gunaan narkoba di kalangan pelajar atau mahasiswa akan berpengaruh negatif terhadap kelangsungan pembangunan nasional. Salah satu hal yang menyebabkan pelajar atau mahasiswa menyalah gunakan narkoba adalah kurangnya informasi tentang bahaya narkoba. Salah satu upaya yang dilakukan untuk memberikan informasi tentang bahaya narkoba adalah melalui penyuluhan dengan metode ceramah. Sebagian besar masyarakat di Desa Battal Kecamatan Panji Kabupaten Situbondo merupakan kalangan remaja dan anak-anak yang berstatus sebagai pelajar maupun sudah bekerja yang membutuhkan penyuluhan mengenai dampak dan bahaya penggunaan narkoba. Penyuluhan ini menambah kesadaran remaja dan anak-anak akan bahaya penyalahgunaan obat-obatan terlarang. Serta meningkatkan kewaspadaan orang tua untuk memberikan pengawasan dan perhatian lebih kepada anak mereka.
\end{abstract}

Kata Kunci: Pengaruh negatif narkoba, Masyarakat Desa, Pelajar

\begin{abstract}
Drugs are very dangerous goods and can damage the nervous system that can change a person's personality for the worse, besides drugs are a source of criminal acts that can destroy general norms and peace. Drug abuse among students will negatively affect the continuity of national development. One of the things that causes students to abuse drugs is the lack of information about the dangers of drugs. One of the efforts made to provide information about the dangers of drugs is through lecture methodology. Most of the people in Battal Village, Panji Subdistrict, Situbondo Regency are teenagers and children who are students or have worked who need counseling about the impact and dangers of drug use. This counseling increases the awareness of teenagers and children about the dangers of substance abuse. As well as increasing the awareness of parents to provide more supervision and attention to their children.
\end{abstract}

Keywords: Negative effects of drugs, Village people, Students 


\section{PENDAHULUAN}

Narkoba merupakan bahan dan obat yang sangat terlarang berdasarkan hukum setiap negara. Narkoba tidak saja merusak generasi mudah bangsa, namun narkoba juga menyebabkan kerusakan pada anggota tubuh terutama dalam berfikir remaja. Bahaya narkoba juga narkotika telah di ketahui semua orang saat ini. Narkoba merupakan wabah yang sangat berbahaya membuat kelemahan iman dan menjauhkan diri manusia kepada Allah merupakan faktor terpenting yang membawa kita masuk ke dalam lingkungan narkoba, jika manusia yang taat beragama pasti akan jauh dari neraka narkoba, tidak mungkin dia akan mengulurkan tangannya pada narkoba, baik membeli, memakai, mengedarkan, maupun menyelundupkannya. Sebab jalan narkoba adalah jalan setan.

Di Indonesia pencandu narkoba perkembangannya semakin hari semakin bertambah pesat. Para pencandu narkoba pada umumnya berusia antara 11 sampai 24 tahun, artinya usia tersebut ialah usia produktif atau usia pelajar, pada awalnya pelajar yang mengonsumsi narkoba biasanya mereka yang sudah mengenal rokok, karena kebiasaan merokok sepertinya sudah menjadi hal wajar di kalangan pelajar, mahasiswa dan remaja saat ini. Dengan adanya penyuluhan di Desa Battal Kecamatan Panji Kaupaten Situbondo yaitu dengan kegiatan pendidikan yang dilakukan dengan cara menyebarkan pesan, menanamkan keyakinan sehingga masyarakat tidak saja sadar, tahu dan mengerti tetapi juga mau dan bias melakukan suatu anjuran yang ada hubungannya dengan kesehatan.

\section{METODE}

Bahan yang digunakan dalam pengabdian masyarakat ialah:

1) penyuluhan pengaruh negatif narkoba bagi masyarakat di Desa Battal Kecamatan Panji Kabupaten Situbondo,

2) Laptop,

3) LCD.

Metode yang digunakan ceramah dan tanya jawab. Kegiatan penyuluhan pengaruh negatif narkoba bagi masyarakat di Desa Battal Kecamatan Panji Kabupaten Situbondo diikuti oleh 18 remaja diuantaranya ada juga perangkat 
Desa yang berasal dari Desa Battal kecamatan Panji Kabupaten Situbondo. Bentuk kegiatan penyuluhan meliputi ceramah. Materi pelatihan dalam penyuluhan pengaruh negatif narkoba bagi masyarakat di Desa Battal Kecamatan Panji Kabupaten Situbondo. Metode kegiatan yang digunakan untuk mencapai tujuan kegiatan pengabdian dilaksanakan di Desa Battal Kecamatan Panji Kabupaten Situbondo melalui beberapa tahapan pelaksanaan kegiatan persiapan, perencanaan, pelaksanaan, evaluasi dan refleksi sebagai berikut;

1) Perencanaan

a. Melakukan kordinasi dengan LPPM STKIP PGRI Situbondo.

b. Sosialisasi kegiatan pengabdian kepada masayarakat dan remaja di Desa Battal.

2) Materi persiapan penyuluhan pengaruh negatif narkoba yaitu;

a. Definisi Narkoba bagi kalangan remaja dan masyarakat, jenis narkoba, dampak negatif narkoba serta upaya pencegahannya.

b. Alternatif solusi dan tahapan pelaksanaan penyusunan laporan pengabdian.

c. Pelaksanaan tahapan kegiatan Pengabdian tahun anggaran berlangsung adalah dari bulan Januari sampai bulan Februari 2021.

3) Pelaksanaan

Langkah-langkah dalam bentuk program yang akan dilaksanakan adalah penyuluhan pengaruh negatif narkoba bagi masyarakat di Desa Battal Kecamatan Panji Kabupaten Situbondo. Metode yang digunakan dalam melakukan penyuluhan terhadap masyarakat dan kalangan remaja di Desa Battal tentang pengaruh negatif terhadap menggunakan narkoba.

4) Evaluasi

Kegiatan Evaluasi dilakukan secara langsung oleh pelaksana. Evaluasi berupa hasil penyuluhan tentang narkoba. Proses evaluasi untuk mengetahui kekurangan dan kendala dalam pelaksanaan kegiatan.

5) Refleksi

Refleksi dilakukan bersama antara pelaksana dan peserta remaja dan masyarakat di Desa Battal. Hal ini dilakukan untuk mengetahui seluruh proses pelaksanaan kegiatan. 
6) Rencana Keberlanjutan Program

Supaya dapat meningkatkan wawasan dan ilmu pengetahuan bagi anakanak remaja dan ibu-ibu rumah tangga di Desa Battal yang mengikuti penyuluhan.

\section{HASIL DAN PEMBAHASAN}

Hasil yang diperoleh dari penyuluhan tentang pengaruh negatif narkoba bagi masyarakat di Desa Battal Kecamatan Panji Kabupaten Situbondo menunjukkan bahwa pengetahuan tentang narkoba, macam dan dampahnya bagi kalangan remaja, ibu rumah tangga masih kurang sehingga, penyuluhan dapat diberikan melalui media informasi seperti demonstrasi bagi masyarakat dengan ceramah. Dalam pemberian penyuluhan metode yang paling efektif adalah demonstrasi karena mudah kita ingat lebih banyak dari yang kita ucapkan dan lakukan. Dalam penyuluhan di Desa Battal Kecamatan Panji Kabupaten Situbondo membahas tentang macam narkoba yaitu; morfin, codein, Heroin (Potauw), methadon, demerol, candu. Program penyuluhan Narkoba dilaksanakan setelah dilakukan tahapan pertama Penyuluhan dilaksanakan selama 1 kali pertemuan dengan objek peserta kegiatan terdiri dari 18 Orang diantaranya ada yang kalangan remaja dan ibu-ibu serta nggota kerabat yang bekerja di Desa Battal.

Faktor yang menyebabkan seseorang ingin mengkonsumsi narkoba adalah perpecahan unit keluarga misalnya perceraian, keluarga yang berpindah-pindah, orang tua yang tidak ada/jarang di rumah dan sebagainya, Pengaruh media massa misalnya iklan mengenai obat-obatan dan zat, perubahan teknologi yang cepat, kaburnya nilai-nilai dan sistem agama serta mencairnya standar moral, meningkatnya waktu menganggur, ketidakseimbangan keadaan ekonomi misalnya kemiskinan, perbedaan ekonomi etno rasial, kemewahan yang membosankan dan sebagainya, menjadi manusia untuk orang lain.

Adapun Bahaya narkoba yang kami sampaikan saat penyuluhan yaitu;

a. Menurut Efeknya

Menimbulkan Halusinogen (halusinasi), Stimulan (seorang pengguna lebih senang dan gembira untuk sementara waktu), Depresan (tidak sadarkan 
diri), Adiktif (kecanduan berat).

b. Menurut Jenisnya

Menimbulkan depresi berat, apatis, rasa lelah berlebihan, malas bergerak, banyak Tidur, gugup, gelisah, selalu merasa curiga, denyut jantung bertambah cepat, rasa gembira berlebihan, banyak bicara namun cadel, rasa harga diri meningkat, kejang-kejang, pupil mata mengecil, tekanan darah meningkat, berkeringat dingin, mual hingga muntah, luka pada sekat rongga hidung, kehilangan nafsu makan, turunnya berat badan.

Dampak negatif penyalahgunaan narkoba terhadap anak atau remaja sebagai berikut:

1) Perubahan dalam sikap, perangai dan kepribadian,

2) Sering membolos, menurunnya kedisiplinan dan nilai-nilai pelajaran,

3) Menjadi mudah tersinggung dan cepat marah,

4) Sering menguap, mengantuk, dan malas,

5) Tidak memedulikan kesehatan diri,

6) Suka mencuri untuk membeli narkoba.

\section{KESIMPULAN}

Narkoba adalah barang yang sangat berbahaya dan bisa merusak susunan syaraf yang bisa merubah sebuah kepribadian seseorang menjadi semakin buruk, selain itu narkoba adalah sumber dari tindakan kriminalitas yang bisa merusak norma dan ketentraman umum. Serta menimbulkan dampak negative yang mempengaruhi pada tubuh baik secara fisik maupun psikologis. Sebaiknya kalangan remaja sekarang harus dibina diluar dan didalam supaya tidak terjerumus ke dalam narkoba dan yang paling berperan penting disini ialah orang tua. Manakala orang tua tidak peduli dengan pergaulan anak-anaknya, maka sudah dipastikan anak tersebut akan terjerumus kedalam narkoba dan apabila sudah terjerumus akan sangat berbahaya, Jika terlalu lama dan sudah ketergantungan narkoba maka lambat laun organ dalam tubuh akan rusak dan jika sudah melebihi takaran maka pengguna itu akan overdosis dan akhirnya kematian. 


\section{UCAPAN TERIMA KASIH}

Segala puji syukur dan terima kasih peneliti panjatkan ke hadirat Tuhan Yang Maha Esa atas berkat dan rahmat-Nya yang telah melindungi dan membimbing sehingga penulis dapat menyelesaikan penyusunan artikel ini tidak akan terlaksana tanpa bantuan dan dukungan dari berbagai pihak. Oleh karena itu dengan segala kerendahan hati, dalam kesempatan ini penulis ingin mengucapkan terima kasih kepada:

1. Bapak Nursalam, M.Pd., selaku Ketua STKIP PGRI Situbondo.

2. Bapak Miftahus Surur, M.Pd., selaku Wakil Ketua STKIP PGRI Situbondo yang selalu meluangkan waktu untuk penulis dan penuh kesabaran membimbing, mengarahkan dan selalu memberikan dorongan, nasehat, semangat, dan dukungan kepada penulis.

3. Ibu Yesi Puspitasari, M. Si., selaku dosen wali yang telah menyertai dan memberi kritik dan saran dalam penulisan artikel ini, sehingga saran tersebut dapat menyempurnakan artikel ini.

\section{DAFTAR PUSTAKA}

Al-Ghifari, A. Generasi Narkoba (Bandung: Mujahid, 2002).

Basri, H. Remaja Berkualitas,Problematika Remaja dan Solusinya (Yogyakarta: Pustaka Belajar, 2006).

Danusantoso, (2000). Patophysiology, konsep klinis proses-proses penyakit. Jakarta: EGC.

Effendy, N. (1998). Dasar-Dasar Keperawatan Kesehatan Masyarakat.Edisi 2. Jakarta: EGC.

Friedman, M.M. (1998). Keperawatan Keluarga Teori dan Praktek, Edisi 3, Alih Bahasa: Debora R. L\&Asy. Y, Jakarta: EGC.

Kartono, K.. Psikologi Remaja (Bandung: Mandar Manju, 2003).

Mellisa Fitri, Sumringah Migunani. (2014). Sosialisasi dan Penyuluhan Narkoba. Vol 3 No 2.

Padmini, D. Narkotika dan Psikotropika (Bandung: Angkasa, 2000).

Sukardi. Bimbingan dan Penyuluhan di Sekolah (Jakarta: Bina Aksara, 2000) 